\title{
多变量解析法の概説，特に主成分分析， 重回帰分析，判別分析を中心にして
}

\author{
金子 精 一 \\ 神奈川県衛生研究所
}

\section{はじめに}

最近の自動化器械はごく少息の試料をインブッ トすれば，要・不要にかかわらず，十数項目に及ぶ 成績を直ちにアウトブットしてくれる。また, 総合 泙価の必要から，通嫦の研究分野でも多項目にわた る成績を求めるのが通例となってきた。

このように，多項目にわたる検查・調查・研究デ 一夕は, 私たちの身のまわりに徐々に山積しはじめ ているが,それらの中にねむっている有効な情報の エッセンスを抽出することは，大変淋難な作業で, その解析はかなり掽れているのが奉状である。それ は, 人の䫓がせいぜい2 項目の関連位しか理解し得 ないからであろう。現在はまさに情報汇濫・混乱の 状況にある。

このような状況を救ってくれる手法のひとつが多 変品解析法である。多変鼠解析法は多項目(変星あ るいは変数）からなるデー夕を何らかの基準に従っ て憋理・統合し，より少い合成された変勇で解釈・ 説明しようとするものである。この手法を用いるこ とにより、私たちは通汶1つ、あるいは2つ, 多く てもせいぜい3つの合成変㩆を適宜選び出し, 多変 占デー夕の情造を解析することができる。そこで, ここでは多変蟽析のより㕕い忍用・普及を望み, その概要について述へることとし，特に同一データ について行なわれる主成分分析，重[回膟分析による 変数選扑，判別分析の連続解析について説明するこ とにする。個々の㐫用例は, 後藤" |H中9)の論文をご参照いただきたい。4 氏 半判別関数を求奶るとを最終目的に各方法を㐫用 されている。

\section{定}

多変舅鯫析は、いくつかの成書によれば次のよう に定義されている。

1) 奥野 ・ 久米・芳賀 $\cdot$ 吉沢 ${ }^{71}$
「多変至解析とは, 互いに相関のある多変量（多 種類の特性值）のデータのもつ特徵を要約し，かつ 所与の目的に応じて総合するための手法である。」

2)ケンドール(浦・竹並訳 $)^{51}$

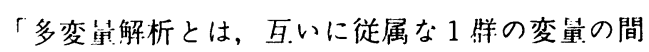
の関係を研究する統計解析の一分野であり,この分 野は従属関係 (dependence) を扱うか, 相互依存関 係( independence)を扱うかによって 2 大別される。」 3) 河 $\left[1^{41}\right.$

「多変㻎解析とは, 変崮の種類が沢山あるとき, 変出同志の間の種々の関係を明らかにして，将来の 予测とか変鱼の分類、合成とかを決めていこうとす る手法である。」

4)柳井・高根 ${ }^{10)}$

1多変重解析とは, 事象そのものの多元的測定と その事象の背後にあると想定される要因の多元的測 分から

(1)事象を簢潔に記述し，

(2)事象に对する要因の影幽を查定し，

(3)要因効果の結合法則を探りあてる ための,一連の統計的手法の総称である。」

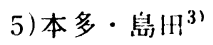

「多変触解析とは，相互に関連する多数の測定デ ー夕を統計的に分析し、複雑なデータを簡潔に要約 したり，データの背後にある現象の構造を明らかに するための方法である。」

これらの定義から明らかなように，多変量解析は 湖々の変垤について単独に統計解析するのではなく，

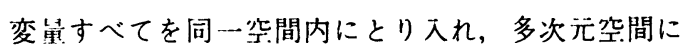
おける相互関係を朋らかにして，変舅の分類・要約, 子测等を行なうものである。そのために、いろいろ の其準にしたがって仮染の合成変景が作られる。合 成変望の作り方によって次のような種類がある。

\section{種類}

変倠の統合奖理・分類, 標本（個体）の分類を目 
表 1 多変睤解析法の種類

\begin{tabular}{|c|c|c|c|c|}
\hline \multirow{2}{*}{\multicolumn{2}{|c|}{ 目 }} & \multirow{2}{*}{ 的 } & \multicolumn{2}{|c|}{ 分 所 法 } \\
\hline & & & 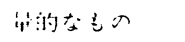 & 钎的なもの \\
\hline \multirow{2}{*}{\multicolumn{2}{|c|}{ 渚変行八祱 }} & 战理·分類 & 市战分分析 & 数蛇化 III, IV 類 \\
\hline & & & 泪于分析 & \\
\hline \multirow{2}{*}{\multicolumn{3}{|c|}{ F澌・哭倸式。発兒 }} & 事[n]集:分析 & 数㶽化 I 類 \\
\hline & & & 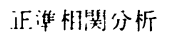 & \\
\hline 摽本 & \multirow[t]{2}{*}{ 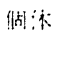 } & \multirow[t]{2}{*}{$\therefore$ 你類 } & 㓝别分析 & \multirow[t]{2}{*}{ 数计化.II 類 } \\
\hline 娭盗 & & & 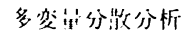 & \\
\hline
\end{tabular}

的上したもの!、表1のと扔り, 主成分分析, 因子

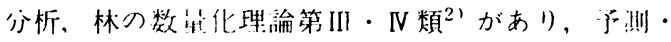

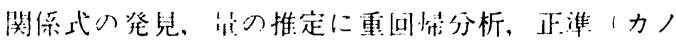
二カル：相関分析, 数旨化 I 類が, 標本の分類, 听

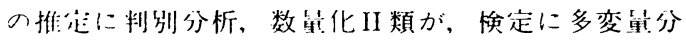
壮分析がある。この表で、的とは的嫢分布等の確

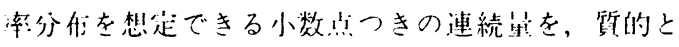
は動物の数，順位等のような整数で現わされる離橵 当在いう。これら千法のうち，本編ではすでに述べ

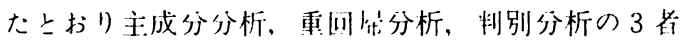
について説明する

\section{理論}

\section{1 . 主成分分析}

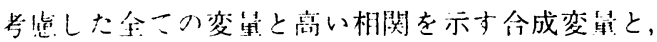

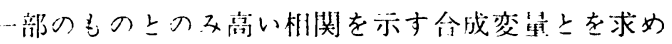
よう上するのが本法である。前者すなわち第 1 主成

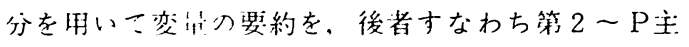
成分在用いこ変搏の分類を行なうことができる。

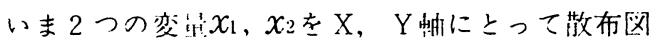

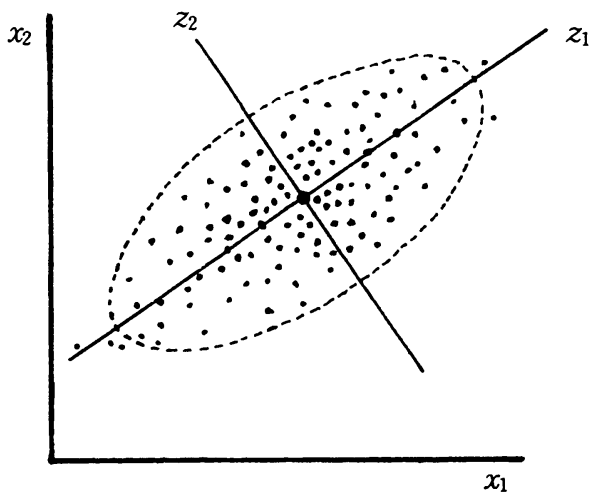

图1主成分分析の理論(1

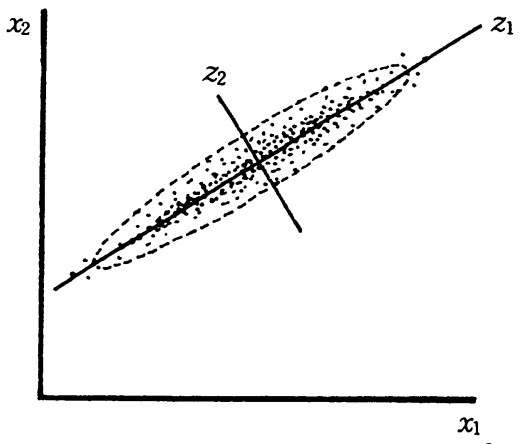

図2主成分分析の理論 2

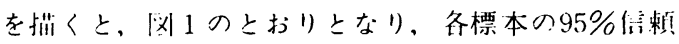
限然は破線のだ円で阿される。そこで、これに新し い來標粗 $z_{1} 、 z_{2}$ 在佊它寸る上，標本の分敬(変動,

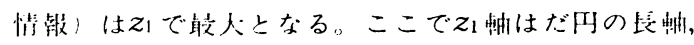

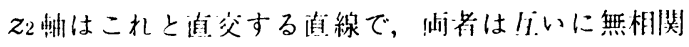
であるっここでもし，だ山が閁2のように长だ円で，

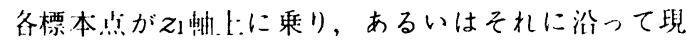

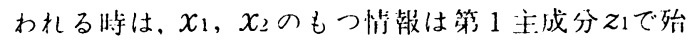
ど説明することができる。すなわち2変早の情報は

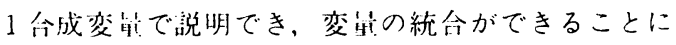
なる、このような分析乎順を多くの变尚について行 なう上、第 2 以济の主成分には，一激の変记とのみ 勇い相関を示す主成分が求められ，それらはそれぞ れ可い!無相関（独方）であるため，これらを用い

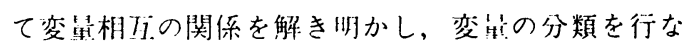
うことができる。

つぎに，各主成分における標本得占（図では $z_{1} お$ よびZ2愽に標本点からおろした兵線の足に相当）を もとに，標本の分類を行なうことができ，これは後 の判別分析に理論上.通ずるものである。

このように，主成分分析は(1)いくつかの変荲を1 つの合成変量（第 1 主成分）に要約して，その標本 得品から個体の順将づけ在行なう，(2)変点の相互関 係を理解し、それらの分類・要約をはかる，(3)目的 に合った主成分を用いて、それらの標本得点をもと に個体の分類を行なう等の目的に利用される。

\section{2 .変量選択を行なう重回攵分析}

与之られた変量 $x_{1} \sim x_{\mathrm{p}}$ を用いて，予測したい変雨 $y$ に最も相関の高い合成変出 $\hat{y}$ を求めるのが, 重回 成分析である。 $x_{1} \sim x_{\mathrm{p}}$ を説明変呈， $y$ を基準変昆と いい, 原データが多変望正規分布するという仮定の もとに, 次の合成変奮 $\hat{y}$ と重相関係数 $\mathrm{R}\left(y\right.$ と $x_{\mathrm{l}} \sim$ $x_{\mathrm{p}}$ の相関(係数) を求为ることができる。 


$$
\hat{y}=b_{0}+b_{1} x_{1}+b_{2} x_{2}+\cdots \cdots \cdots+b_{p} x_{p}
$$

ここで、私たちは $y$ を予测する上で有効な変舅は $x_{1} \sim x_{\mathrm{p}}$ のうちどれか, できればあまり有効でないも のは除いて，もっと管単な秝测式を作りたいと考之 るであろう。このような場合には変禹選扑を行なう 重回㤝分析を行なう。それには，F佔，決定係数( $\left.\mathrm{R}^{2}\right)$, 重相関係数等を最大に保つことを条件に，有効でな い変出からひとつずつ減らし重回㫦分析を繰り返し 行なう変武減少法, 有効なものからひとつずつ堌や して行なう変卓增加法, 活者を闰時に行なう変甾增 減法のいずれかを懒用すればよい。このようにして $y$ を一澎するために佮效な説明変界の選扑ができる。 この結果は重回悑式を作る埸合のみではなく，判別 式 (関数)を作る場合にも参考になるものである。

\section{3. 判別分布}

ミたつのデー夕辡，たとえば健康な牛の併と病気 の牛の桷を判別したい時，その線型関数を求めるの が判別分析である。関数は判別式ともいわれ，重[回

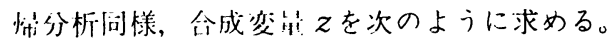

$$
z=a_{0}+a_{1} x_{1}+a_{2} x_{2}+\cdots \cdots \cdots+a_{1} x_{1}
$$

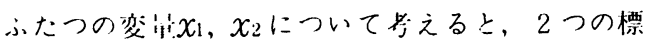

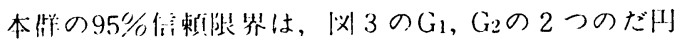
で表わされる。いま，2つのだ川の交占を近る直線

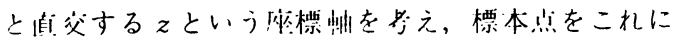
怰跡させると，斜線で表わした灌判別の確率領域す

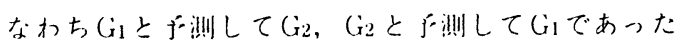

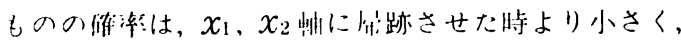

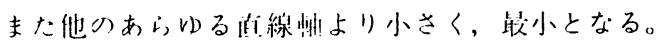

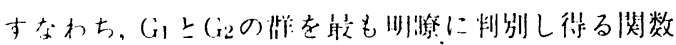

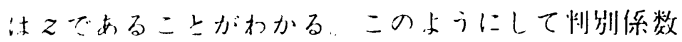

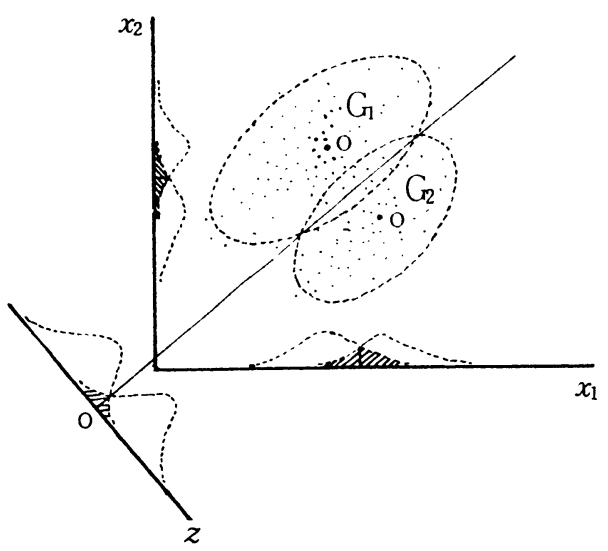

図 3 判別分析の理論
の $a_{0} \sim a_{\mathrm{p}}$ が定められたら，標本（牛）の $x_{1} \sim x_{\mathrm{p}}$ 実測 值を式に代入して $z$ の傎を求める。值が正または 0 であれば健康牛，負であれば病牛と判別する。この

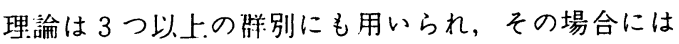
通诮所羊の数だけ関数を求め, 標本は最大の $z$ 值を示 した㲏に属するものと判別する。

$$
\text { 応用 }
$$

ここでは，1つの多変舅データについて，主成分 分析，変星選択を行なう重回修分析，判別分析を通 して行ない, 目的に台った判別関数を求める過程に ついて颜明する。

まず，表2のような多変量デー夕专用いて主成分 分析を行ない，各主成分の情造係数，標本得点を求 める。第 2 主成分上第 3 主成分, 第 2 主成分と第 4 主成分，……の組合せについて，構造ベクトルを 用いて順次 X P Y 2 次它平面に各变苗の位真を打点 していく。変動が同じものは互いに近い所，翼なる ものは遠い听に配萳されるため，近いもの同志まと

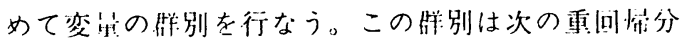
析，判別分析を行なうにあたり，あらかじか変鼠の 相不并係を理鲜しておく上で重要な密義をもち，そ の伯では主成分分析は，本来最終目的のために念用 する丁法ではなく，解析の途中で用いるもののひと

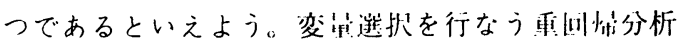

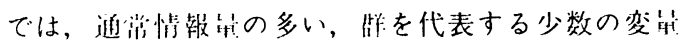
がケ浴効果の大きいものとして採扑される。问湖の

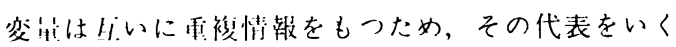

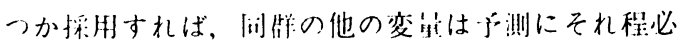
岁ではなくなるわけである。

つぎに，表2のデータ们端に基準となるyのデー

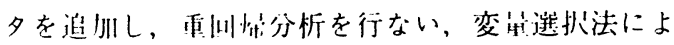
るお测に有效な変早の順位づけを行なう。順位づけ

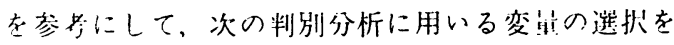

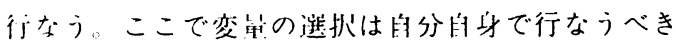
であること志志れてはならない。コンピュータの打 ち出した有効変出の順序を参考に，採用すべきもの，

\section{表 2 多変卢解析のためのデー夕}

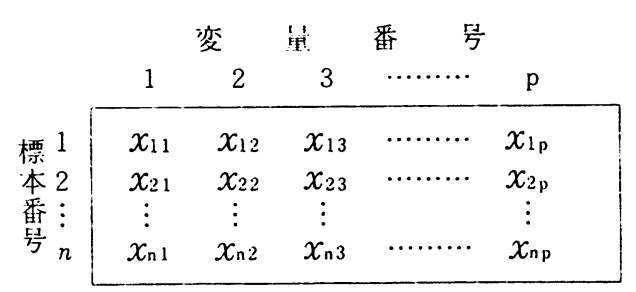


No. $5, \quad 1-4$ (1980)

採用しなくてもよいものにまず分ける。その区分は 基準に選んだ $\mathrm{F}$ 值, 決定係数, 重相関係数等の值が ある值を維持できるまでの変舅を採用するか，変量 減少法で急激に基準の値が低下する直前，增加法で 急激に上昇する直後までの変量を採用するとよい。 つぎに，採用すべき変最が決まったら，判別関数を 用い予測を行なうにあたって困難をともなう变最, たとえば娭查・調查が難しく複雑なもの，他の人・ 所に依頼するため、データ入手が不安定なもの等, 問題のありそうな変是をとりあげ，よく倹討し，採 用できるもののみ残し，採用したくても無理なもの は除く。このようにして，残った変㞷を用い判別分 析を行なうが，判別の精度が低く不満足な場合は， 主成分分析による変荲の篻別成績を参考にして，採 用したくても無理なため除いた変舅と同群の他の代 表变倠をとり入れて判別分析を行なうとよい。

判別分析により判別関数の係数, 定数, マハラ八 ビスの距離, $\mathrm{F}$ 恰定, 理諭的適中率, 事後予測（表 2 データにおける子测），事後子測適中率等を求力， 以後得られるデータについても, 判別関数を用い事 前判別を行なう。 (かねこせいいち)

\section{弓! 用文献}

1）後藤信男ら：下顎骨の形状による近交采マウス
西.系の同定一判別分析の適用一獣医科学と統計利 用, No. 5，20-25， 1980 .

2 ) 林知已夫：数星化の方法. 東京経済新報社, 東 京, 1974.

3 ) 本多正久, 島田一明: 経営のための多変望解析 法. 産業能率短大出版部, 東京, 1977.

4 ) 河口至商：多変早解析入門. 森北出版, 東京, 1973.

5 ) ケンドール（浦昭二訳）：多変聂解析の基礎. サイエンス社, 東京, 1972.

6 ) 中村隊三：判別関数による乳牛の周産期におけ る疾病発生の予測. 獣医科学と統計利用, No. 5 , 15-19, 1980.

7 ) 奥野忠一ら：多变舁解析法. 日科技連, 東京, 1971.

8 ）高橋正少，金子精一：主成分分析による食中毒 発生要因（気息・海況14要因）の相互関係解析. 獸医科学と統計利用, No. 5, 5-8, 1980.

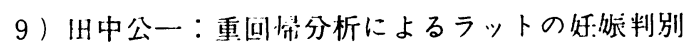
寄与要因（血液性状）の推定. 獣医科学と統計利 用, No. 5, 9-14, 1980 .

10）柳井掯夫, 高根芳雄: 多変翼解析法. 朝食書店, 東京, 1977 . 